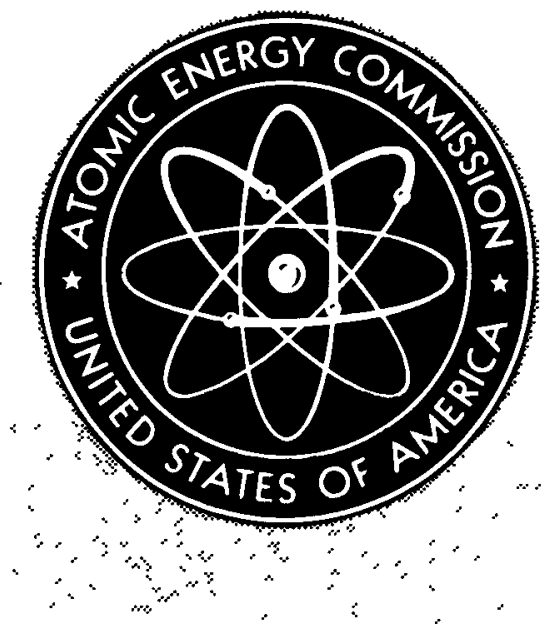

\title{
MASTER
}

TID-16315 (Del.)

\section{ADVANCED NUCLEAR ROCKET MATERIALS RESEARCH}

May 31, 1962

Division of Reactor Development

United States Atomic Energy Commission Washington 25, D. C. 


\section{DISCLAIMER}

This report was prepared as an account of work sponsored by an agency of the United States Government. Neither the United States Government nor any agency Thereof, nor any of their employees, makes any warranty, express or implied, or assumes any legal liability or responsibility for the accuracy, completeness, or usefulness of any information, apparatus, product, or process disclosed, or represents that its use would not infringe privately owned rights. Reference herein to any specific commercial product, process, or service by trade name, trademark, manufacturer, or otherwise does not necessarily constitute or imply its endorsement, recommendation, or favoring by the United States Government or any agency thereof. The views and opinions of authors expressed herein do not necessarily state or reflect those of the United States Government or any agency thereof. 


\section{DISCLAIMER}

Portions of this document may be illegible in electronic image products. Images are produced from the best available original document. 


\section{LEGAL NOTICE}

This report was prepared as an account of Government sponsored work. Neither the United States, nor the Commission, nor any person acting on behalf of the Commission:

A. Makes any warranty or representation, expressed or implied, with respect to the accuracy, completeness, or usefulness of the information contained in this report, or that the use of any information, apparatus, method, or process disclosed in this report may not infringe privately owned rights; or

B. Assumes any liabllities with respect to the use of, or for damages resulting from the use of any information, apparatus, method, or process disclosed in this report.

As used in the above, "person acting on behalf of the Commission" includes any employee or contractor of the Commission, or employee of such contractor, to the extent that such employee or contractor of the Commission, or employee of such contractor prepares, disseminates, or provides access to, any information pursuant to his employment or contract with the Commission, or his employment with such contractor.

\section{This report has been reproduced directly from the best} available copy.

Printed in USA. Price $\$ 0.50$. Avallable from the Office of Technical Services, Department of Commerce, Washington 25, D. C. 


\section{Introduction}

This report is being circulated to stimulate interest in research on materials for extremely high temperature nuclear rocket applications. It should also guide any interest that might be stimulated so that research effort will be expended on materials believed to be of potential use in advanced nuclear rocket reactors.

We recognize that the immediate $U$. So capability to conduct the research suggested is extremely limited. In view of this limited capability we hope that the initial impact of this report will be to encourage competent research organizations to obtain the equipment and experience required to conduct such research.

Frank Ko Pittman, Director Division of Reactor Development 
A meeting was held on May 9, 1962, in the AEC offices at $1717 \mathrm{H}$ Street, N.W., Washington, D.C. for the purpose of:

(1) Defining the materials problems inherent in advanced nuclear rockets.

(2) Selecting the materials that appear most promising for advanced nuclear rockets.

(3) Considering the available information on the promising materials.

(4) Listing the materials properties and/or other information that should be obtained and where possible, establishing the relative urgency of the requirement.

The following individuals active in extremely high temperature materials research participated in the meeting:

\begin{tabular}{|c|c|}
\hline \multirow{7}{*}{$\begin{array}{l}\text { Robert W. Hall } \\
\text { Melvi: G. Bowman } \\
\text { Haruo Kato } \\
\text { Colt D. Pears } \\
\text { Harry S. Parker } \\
\text { Allen D. Franklin } \\
\text { Vincent P. Calkins }\end{array}$} & \\
\hline & LASSL \\
\hline & Bureau of Mines \\
\hline & Southerm Research Institute \\
\hline & Bureau of Standards \\
\hline & Bureau of Standards \\
\hline & GE (NMPO) \\
\hline
\end{tabular}

The AEC and NASA headquarters staffs were represented by:

$\begin{array}{lll}\text { Merrill J. Whitman } & \text { - AEC - Chairman } \\ \text { William L. R. Rice } & \text { - AEC } \\ \text { F. Carl Schwenk } & \text { - NASA (SNPO) } \\ \text { John E. Morrissey } & \text { - AEC (SNPO) } \\ \text { James Gangler } & \text { - NASA } \\ \text { Harold Hessing } & \text { - NASA }\end{array}$

Selection Criteria - It was agreed that materials to be considered would not be eliminated because of weight (density), nuclear cross-section, brittleness, or cost. The minimum requirement was that the material in question have a melting point over $3500^{\circ} \mathrm{F}$.

It was agreed that information on any material of interest would include the following:

A. Compatibility, with

(1) Nuclear Fuel

(2) Hydrogen

B. Physical Properties
(1) Thermal Expansion
(2) Thermal Conductivity
(3) Specific Heat
(4) Emittance
(5) Vapor Pressure

C. Mechanical Properties

(1) Tensile Modulus

(2) Stress Rupture

(3) Elongation (Ductility)

(4) Fabricability 
Materials selected as being of interest are as follows: Metals, Carbides, Sulfides, Nitrides, Oxides, and Borides. Each class will be duscussed in turn.

\section{Metals}

Metals of most interest are listed in Table Io The metals osmium and iridium were eliminated because of lack of information on their properties. Before they would be considered for engineering applications, either alloyed or unalloyed, more work of a basic nature needs to be done. The final order agreed upon is as follows: W (thermal reactor use), W-Re alloys, $\mathrm{W}-\mathrm{Ta}$ alloys, $\mathrm{Re}$, Ta-W alloys, Mo (thermal reactor use), $\mathrm{Ta}$, and $\mathrm{Mb}$ (in decreasing order of attractiveness)。

$W$ - It is important that the practical limit of uranium dioxide addition addition to $\mathrm{W}_{-} \mathrm{JO}_{2}$ fuel elements be established. Information should be obtained on the effect of $\mathrm{UO}_{2}$ loading on: (1) Fabricability, (2) Chemical and Metallurgical stability, (3) Fuel Retention, (4) Performance, and (5) Strength and Physical Properties. It is particularly important that the diffussion coefficient of hydrogen through tungsten as a function of temperature be determined.

Re and Re Alloys - It must be recognized that at present Re is in short supply, This is not considered sufficient justification to eliminate its use. In general, it is necessary that the metallurgy of Re be studied to the same extent as that of tungsten. As with tungsten it is important that $R e_{\text {, }}$ or Re alloys, be evaluated for use as fuel cladding and matrix materials. The diffusion coefficient of hydrogen through Re should be determined as a function of temperature.

$\mathrm{Ta}$ and $\mathrm{Ta}$ Alloys - The biggest problem with $\mathrm{Ta}$ is its susceptibility to hydriding and subsequent disintegration. It is vital that we obtain information on the effect of hydrogen on the mechanical properties of tantalum bearing alloys, with the hope that alloys can be prepared having resistance to hydriding. Data should be obtained on the solubility of hydrogen in tantalum alloy systems (hydrogen uptake rate as a function of temperature and pressure). Research should be initiated to obtain a coating material for $\mathrm{Ta}$ that would prevent it from hydriding.

Mo - It is recognized that Mo has an advantage over $W$ with respect to weight $_{9}$ cross-section, and ease of fabrication. It was eliminated because of low strength and high vapor pressure at operating temperatures.

General - No special emphasis on the metal phase diagrams is considered necessary. High temperature $X$-ray equipment is very badly needed to study refractory metal alloys at high temperatures. For all of these metals it is important that stress-strain curves, rather than simple stress at rupture, be known, since many of them yield continually over the entire stress range at high temperatures。

\section{Graphite}

A large amount of work is needed on graphite. Included is work on attainment of theoretical density, development of a scientific basis of fabrication technology, development of uniform raw materials, and control of directional thermal and mechanical properties. 
III. Carbides

The order of compounds, according to decreasing interest, is as follows: $\mathrm{HfC}, \mathrm{HfC}-\mathrm{ZrC}, \mathrm{TaC}, \mathrm{MoC} .67-\mathrm{NbC}, \mathrm{GdC}, \mathrm{TiC}, \mathrm{WC}, \mathrm{Mo}_{3} \mathrm{C}_{2}$. The list is intended to include the material listed as a single compound and in combination with uranium. WC is given low rating because of its melting point.

Not included, but of interest, are the compounds $\mathrm{UWC}_{2}$ and $\mathrm{UMOC}_{2}$. The stability of these compounds should reduce the loss of uranium by diffusion through the cladding. Also not included is consideration of $\mathrm{UC}$ and $\mathrm{UC}_{2}$. The effort on the carbides of uranium is very extensive and should provide the information desired.

The following information is desired for all the compounds 1 is ted, and, in fact, applies equally to the carbides, oxides, nitrides, and borides:

(1) High temperature mechanical properties as a function of composition (stoichionetry).

(2) Methods of synthesis and fabrication into useful shapes (thin sheets, rods, etc.).

(3) Means of controlling composition over a wide temperature range. Specifically, information is desired on:

(1) Melting points of nonstoichemetric HfC as a function of composition.

(2) Mechanical properties of $\mathrm{HfC}$ and $\mathrm{ZrC}$ as a function of composition.

(3) Thermal-chemical properties of $U$ bearing ternarys UHfC, UZrC, UT2C and UNbC up to 50 atomic per cent J.

IV. Sulfides

of the sulfides, only us is of interest. It is desired that information be obtained on melting points, stoichiometry, and the synthesis and fabrication of this material. ANL should provide much of this information within the scope of its existing effort.

V. Nitrides

The nitrides of interest (in decreasing order) are Un, HfN, ZrN, TiN, and $B N$. A substantial effort is now underway on UN, including a study of synthesis, fabrication, and Irradiation stability, The nitrides, in general, are less promising than the carbides. Nitrides clad with $W$ might be useable since WN is not stable at high temperature. It is therefore important that $W$ be studied for possible use as a nitrogen barrier. If it is an acceptable barrier the nitrides should be screened for application. 
VI. Oxides

Hydrogen reduction negates the use of oxides for nuclear rocket applications. They are limited also by their brittle behavior. Beo is of interest as a moderator material, and, if temperatures are kept below $1600^{\circ} \mathrm{C}$, might have structural applications. Uranium dioxide is of course of interest as a fuel material, but only if clad.

It is felt that a small amount of exploratory research on fused $\mathrm{ThO}_{2}$ would be helpful to establish its potential as a structural material.

VII. Borides

The borides appear promising as structural materials, since they are not as brittle as the oxides and are more resistant to thermal shock than the oxides and carbides. It is anticipated that they will be compatible with the carbides. Order of preference is not clear, but it is intuitively felt that $\mathrm{TaB}_{2}$ and $\mathrm{ThB}_{4}$ would be most interesting to study。

Merrili J. Whitman

Fuels Materials Development Branch

Division of Reactor Development 
TABLE I.

MATERIALS OF INTEREST FOR NUCLEAR ROCKET APPLICATIONS

A. METALS

W
Re
Ta
Mo
Nb
Os
Ir

B. CARBIDES

Graphite

HfC

$\mathrm{ZrC}$

$\mathrm{TaC}$

$\mathrm{NbC}$

MoC $.67^{-\mathrm{NbC}}$

TiC

WC

$\mathrm{Mo}_{3} \mathrm{C}_{2}$

$\mathrm{UWC}_{2}$

UMOC 2

Ternary Mixtures

C. URANIUM SULFIDE

D. NITRIDES

UN

HeN

$\mathrm{ZrN}$

TIN

BN
E. OXIDES

$$
\begin{aligned}
& \mathrm{UO}_{2} \\
& \mathrm{BeO}^{2} \\
& \mathrm{ThO}_{2} \\
& \mathrm{ZrO}_{2} \\
& \mathrm{HfO}_{2} \\
& \mathrm{CeO}_{2} \quad\left(\mathrm{Ce}_{2} \mathrm{O}_{3}\right) \\
& \mathrm{MgO}
\end{aligned}
$$

F. BORIDES

$$
\mathrm{TaB}_{2}
$$

$\mathrm{ThB}_{4}$

$\mathrm{HfB}_{2}$

$\mathrm{ZrB}_{2}$

WB

$\mathrm{TiB}_{2}$ 